
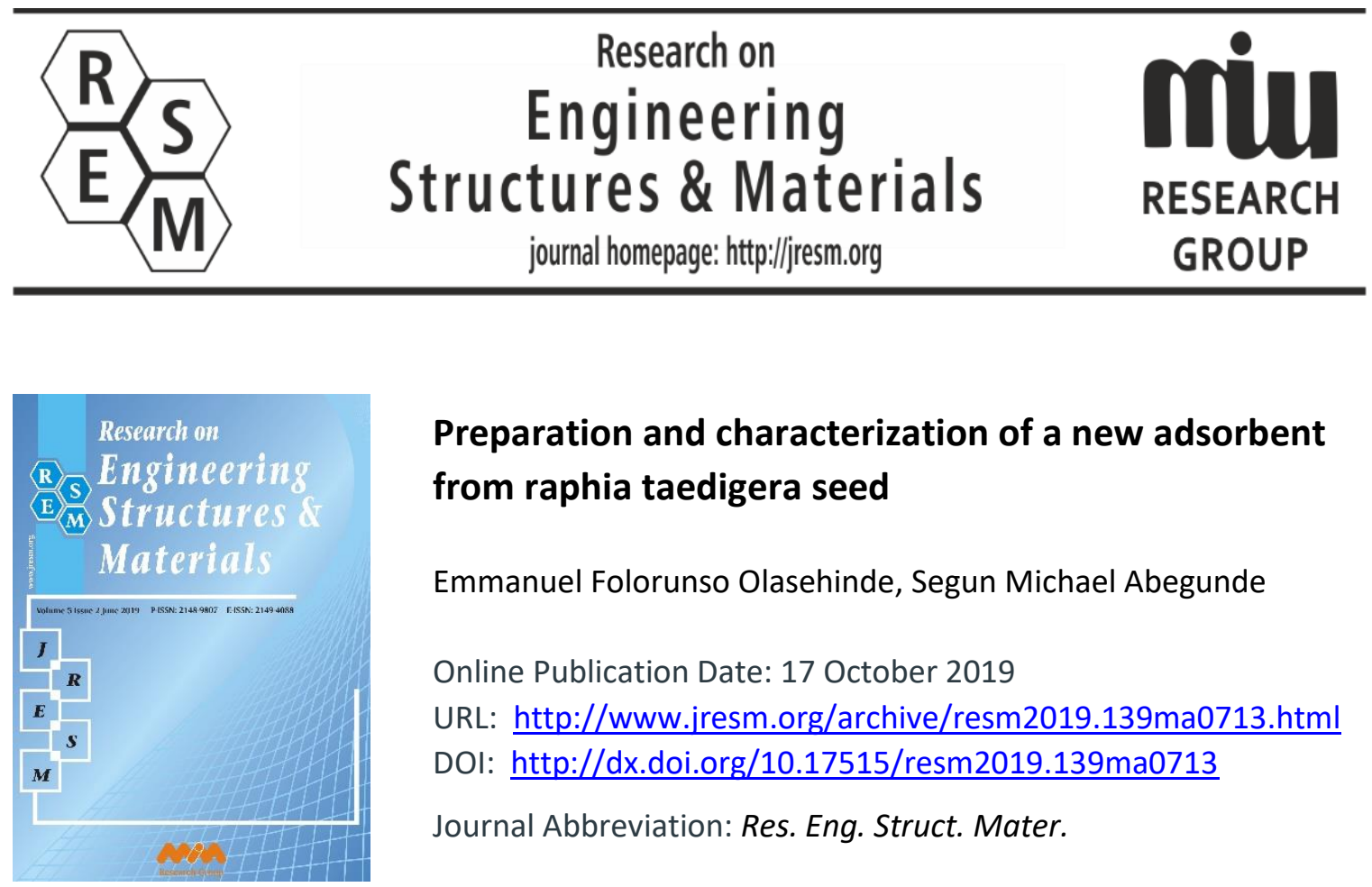

\title{
Preparation and characterization of a new adsorbent from raphia taedigera seed
}

Emmanuel Folorunso Olasehinde, Segun Michael Abegunde

Online Publication Date: 17 October 2019

URL: http://www.jresm.org/archive/resm2019.139ma0713.html

DOI: http://dx.doi.org/10.17515/resm2019.139ma0713

Journal Abbreviation: Res. Eng. Struct. Mater.

\section{To cite this article}

Olasehinde EF, Abegunde SM. Preparation and characterization of a new adsorbent from raphia taedigera seed. Res. Eng. Struct. Mater., 2020; 6(2): 167-182.

\section{Disclaimer}

All the opinions and statements expressed in the papers are on the responsibility of author(s) and are not to be regarded as those of the journal of Research on Engineering Structures and Materials (RESM) organization or related parties. The publishers make no warranty, explicit or implied, or make any representation with respect to the contents of any article will be complete or accurate or up to date. The accuracy of any instructions, equations, or other information should be independently verified. The publisher and related parties shall not be liable for any loss, actions, claims, proceedings, demand or costs or damages whatsoever or howsoever caused arising directly or indirectly in connection with use of the information given in the journal or related means.

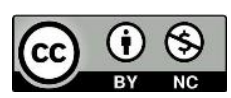

Published articles are freely available to users under the terms of Creative Commons Attribution - NonCommercial 4.0 International Public License, as currently displayed at here (the "CC BY - NC"). 


\title{
Research on Engineering Structures \& Materials \\ journal homepage: http://jresm.org
}

Research Article

\section{Preparation and characterization of a new adsorbent from raphia taedigera seed}

\author{
Emmanuel Folorunso Olasehinde ${ }^{1, a}$, Segun Michael Abegunde ${ }^{* 2, b}$ \\ ${ }^{1}$ Department of Chemistry, Federal University of Technology, Akure, Nigeria \\ ${ }^{2}$ Department of Science Technology, Federal Polytechnic, Ado-Ekiti, Ekiti State, Nigeria
}

\begin{abstract}
Article Info
Abstract

Article history:

Received 13 Jul 2019

Revised 10 Sep 2019

Accepted 16 Sep 2019

Keywords:

Raphia taedigera;

adsorbent;

carbonization;

activation;

methylene blue;

SEM

There has been widespread research and engagement in recent years on the use of plant material in preparing porous carbon for wastewater treatment. In this study, new biochars (BCs) impregnated with $0.1 \mathrm{M}$ sulphuric acid (RTA) and $0.1 \mathrm{M}$ sodium hydroxide (RTB) were prepared. The BCs and raw seed [RTR] were characterized using scanning electron microscopy (SEM), Fouriertransform infrared (FTIR) spectrophotometer, and thermogravimetric/Differential thermal analyser. [TGA/DTA) to determine their morphology, spectral bands and thermal behaviour respectively. RTR showed a scattered aggregated surface microstructure, while both RTA and RTB gave aggregated rough surfaces with high number of pores. The FTIR analysis showed significant changes in term of band shift, bands disappearances, and new band formations due to pyrolysis and activation of the BCs. The results of the TGA/DTA revealed that RTA and RTB have better thermal stability than RTR, with the maximum degradation temperature of RTR, RTA, and RTB occurred at $380^{\circ} \mathrm{C}, 425^{\circ} \mathrm{C}$ and $410^{\circ} \mathrm{C}$ respectively. Adsorption efficiencies ranged from 81.671 to $99.743 \%$ for performance evaluation on the BCs using different adsorbent dosages and the initial concentrations of methylene blue solutions. These preliminary investigations suggest that biochars prepared from Raphia taedigera seed can be used for methylene blue removal from wastewater.
\end{abstract}

(C) 2019 MIM Research Group. All rights reserved.

\section{Introduction}

In recent years, heavy metals and textile dyes have been considered the most ubiquitous contaminants of water worldwide. Water pollution is a major concern in our environment, and so providing a solution to this issue will be of obvious benefit to humans [1]. Over the years, adsorption has been recognized as one of the most reliable and efficient methods of removing organic and inorganic pollutants from industrial wastewater. Activated carbon (AC) has been undoubtedly recognized as the most common and widely employed adsorbent for wastewater treatment, given its simplicity of use, low cost, renewable nature, availability, and non-toxicity; its porous structure over large surface areas makes it a material of choice as an effective adsorbent [2 - 4]. With the introduction of stricter environmental regulations, the demand for porous carbons has progressively increased $[5,6]$. Recently, there have been reports on several

*Corresponding author: abegundes@gmail.com

a orcid.org/0000-0002-3909-1283; b orcid.org/0000-0002-6688-5230

DOI: http://dx.doi.org/10.17515/resm2019.139ma0713

Res. Eng. Struct. Mat. Vol. 6 Iss. 2 (2020) 167-182 
treatment processes by which to remove contaminants from wastewater, including degradation by photocatalytic processes [7-12]; the Fenton process [13]; photo-Fenton processes [14]; sono-chemical degradation [15]; chemical coagulation/flocculation, ozonation, cloud point extraction, oxidation, nano-filtration, chemical precipitation, ion exchange, reverse osmosis, and ultra-filtration [16-20]; and modified processes such as those combining ultrasound with adsorption-desorption processes [21-24]. However, among these, adsorption techniques have gained favour, owing to their simplicity, costeffectiveness, and efficiency in removing pollutants that are too stable for conventional methods [8, 25-29]. Recently, the idea of using locally sourced materials to prepare adsorbent materials for water and effluent treatment has gained popularity among environmentalists and material engineers. Given the exorbitant cost of commercial AC, there is a need to develop a low-cost and high-performance adsorbent from readily available and locally sourced alternative materials. Several agricultural waste products have been utilized [30], including cotton stalks [31], cereal by-product [6], bamboo [32], acorn shells [33], groundnut shells [34, 35], bagasse [36], cow bone powder [37], palm oil stones [38], coconut shells [39], tobacco residues [40], olive stones [41], apricot stones [42], nutshells [43], walnut shells [41], pine cones [44], and cherry stones [45].

Little information is currently available on Raphia taedigera, despite having been in existence for centuries. The plant remains quantitatively and qualitatively untapped in terms of their potential applications. $R$ taedigera is native to Brazil, Cameroon, Costa Rica, Nicaragua, Nigeria, and Panama [46-50], and grows in swampy forests along streams. It produces egg-sized fruits of about 5-7 cm long and $3 \mathrm{~cm}$ in diameter, which are covered by imbricate glossy reddish-brown scales; each fruit contains one seed. A well-dried seed is hard and has a brown outer part and white shiny inner part.

In literature, no study has clearly evaluated the possibility of using $R$ taedigera seed as an adsorbent. With recent developments in the need to source locally for available materials to prepare adsorbent, since metal ion and dye pollutants pose a serious threat to biological and environmental sources, given their harmful effects on human health and the environment [51, 52 hence; a need to check the potential of $R$. taedigera seed as a useful adsorbent This present study is aimed at preparation and characterization of adsorbent from Raphia taedigera seed considered as waste, for the recovery of methylene blue dye from aqueous solution.

\section{Materials and Methods}

\subsection{Sample collection and treatment}

$R$. taedigera seeds were obtained locally from a farmland in Ise-Ekiti, washed and sundried for several days until moisture evaporation was completed. The dried samples were crushed using 911MPE-24 laboratory crusher. The crushed sample was kept in an airtight plastic container for further analysis.

\subsection{Preparation of Raphia taedigera adsorbent}

\subsubsection{Carbonization of samples}

The carbonization was done as reported by [53]. The dried and crushed $R$. taedigera seeds were carbonized by placing $100 \mathrm{~g}$ of the seed in a muffle furnace (Carbolite, Sheffield, England, LMF4) at $350^{\circ} \mathrm{C}$ for about 2 hours. During carbonization, an exhaust pipe was used to remove steam to set the process oxygen-deficient. This made the material to thermally decompose to porous carbonaceous materials and compounds of the hydrocarbon. After the carbonization process, the carbonized biochars were 
allowed to cool to room temperature, washed with double distilled water to a $\mathrm{pH}$ of about 7 and dried to constant weight in an oven at $105^{\circ} \mathrm{C}$. The carbonized biochars were sieved with 100-mm mesh Tyler sieve and kept in an airtight polythene bag.

\subsubsection{Activation of the carbonized samples}

The activation was done as reported by [53]. Both acidic and basic activations were done on the material. $20 \mathrm{~g}$ carbonized material was carefully weighed and quantitatively transferred into a clean and dry $500 \mathrm{~mL}$ beaker containing $200 \mathrm{~mL} 0.1 \mathrm{M}$ sulphuric acid for acidic activation and $200 \mathrm{~mL}$ of $0.1 \mathrm{M}$ sodium hydroxide was used for alkaline activation of another $20 \mathrm{~g}$ of the carbonized material. The contents of the beakers were carefully homogenized and left to stand for about 24 hours. The impregnated materials were diluted with $200 \mathrm{~mL}$ distilled water to rinse off the sulphuric acid and sodium hydroxide used as activating agents respectively. The process of washing continued until the $\mathrm{pH}$ of 7.0 was attained and transferred into an oven and dried to constant weight at $105^{\circ} \mathrm{C}$ for about 4 hours. It was sieved with 100 $\mathrm{mm}$ mesh to obtain a fine powder of Raphia taedigera activated biochars for both the acid (RTA) and the base (RTB). The RTA, RTB, and RTR (raw Raphia taedigera seed powder) were stored in a separate airtight plastic container for further use.

\subsection{Material Characterization}

The morphology of the samples was carried out using scanning electron microscopy (SEM) to evaluate the microstructure characteristics. TGA/DTA was used to determine the thermal behaviour of the samples using thermogravimetric Analyzer Perkin-Elmer TGA 4000 at the temperature range of $30-900^{\circ} \mathrm{C}$ while Fourier-transform infrared spectrophotometer (FTIR) was engaged to evaluate the molecular bonding present in the materials.

\subsection{Preparation of Methylene Blue (MB)}

$100 \mathrm{mg} / \mathrm{L}$ of methylene blue (MB) stock solution was prepared by quantitatively dissolving $0.1 \mathrm{~g} \mathrm{MB}$ in distilled water in $1,000 \mathrm{~mL}$ volumetric flask and made up to the mark with distilled water. The maximum absorption wavelength was determined by UV spectrophotometer. $0.1 \mathrm{M}$ of $\mathrm{HCl}$ and $0.1 \mathrm{M} \mathrm{NaOH}$ solutions were also prepared to adjust the $\mathrm{pH}$. All reagents used were of analytical grade.

\subsection{Evaluation of Effect some Parameters on the Adsorption}

\subsubsection{Effect of Adsorbent Dose}

The effect of the adsorbent dose was experimented using different adsorbent dosages of $0.1 \mathrm{~g}, 0.3 \mathrm{~g}, 0.5 \mathrm{~g}, 0.5 \mathrm{~g}, 0.7 \mathrm{~g}$ and $0.9 \mathrm{~g} .10 \mathrm{~mL}$ of $100 \mathrm{mg} / \mathrm{L} \mathrm{MB}$ was introduced into a beaker containing each of the adsorbent doses for 15 minutes at room temperature. The solution was filtered, and the concentrations of the filtrates were determined using a UV spectrophotometer and the amount of MB adsorbed was calculated using $E q 1$.

$$
q_{e}=\frac{\left(C_{o}-C_{e}\right) V}{W}
$$

Where, $q_{e}$ is the amount of MB adsorbed per unit mass in $\mathrm{mg} / \mathrm{g}, C_{o}$ is the initial MB concentration in $\mathrm{mg} / \mathrm{L}, C_{e}$ is the $\mathrm{MB}$ concentration at equilibrium in $\mathrm{mg} / \mathrm{L}, V$ is the volume of MB solution in liter and $W$ is the mass of the adsorbent in grams. 
The adsorption efficiency was calculated using the equation below:

Adsorption efficiency $=\frac{\left(C_{o}-C e\right)}{C_{o}} \times 100$

\subsubsection{Effect of Initial Solution Concentration}

The effect of initial concentrations of MB was evaluated using different concentrations of $20 \mathrm{mg} / \mathrm{L}, 40 \mathrm{mg} / \mathrm{L}, 60 \mathrm{mg} / \mathrm{L} .80 \mathrm{mg} / \mathrm{L}$ and $100 \mathrm{mg} / \mathrm{L} .0 .5 \mathrm{~g}$ of the adsorbent was introduced into a conical flask containing $10 \mathrm{~mL}$ of each of the solution and allowed to stand for 15 minutes at room temperature. The solution was filtered, and the concentrations of the filtrates were determined. The amount of MB adsorbed and percentage efficiency of the adsorbents were calculated using equations 1 and 2 respectively.

\section{Results and Discussion}

\subsection{Surface morphology studies.}

The surface morphology studies of RTR, RTA and RTB were done using Scanning electron microscopy and presented in Figures 1,2 and 3 respectively. The photomicrographs at a magnification of 300x, 500x and 1000x are given as A, B and C respectively. As expected, pyrolysis and surface activation, altered to a noticeable level, the surface morphologies of the biochars (RTA and RTB) compared to raw Raphia taedigera (RTR). Figure 1 shows scattered aggregated surface, while figures 2 and 3 show aggregated and rough surface morphology with links between the surface particles creating many more pores at the surfaces. The roughness and uneven nature of the surfaces observed in figures 2 and 3 are due to the activation of the porous carbon using $\mathrm{H}_{2} \mathrm{SO}_{4}$ and $\mathrm{NaOH}$ solutions respectively.

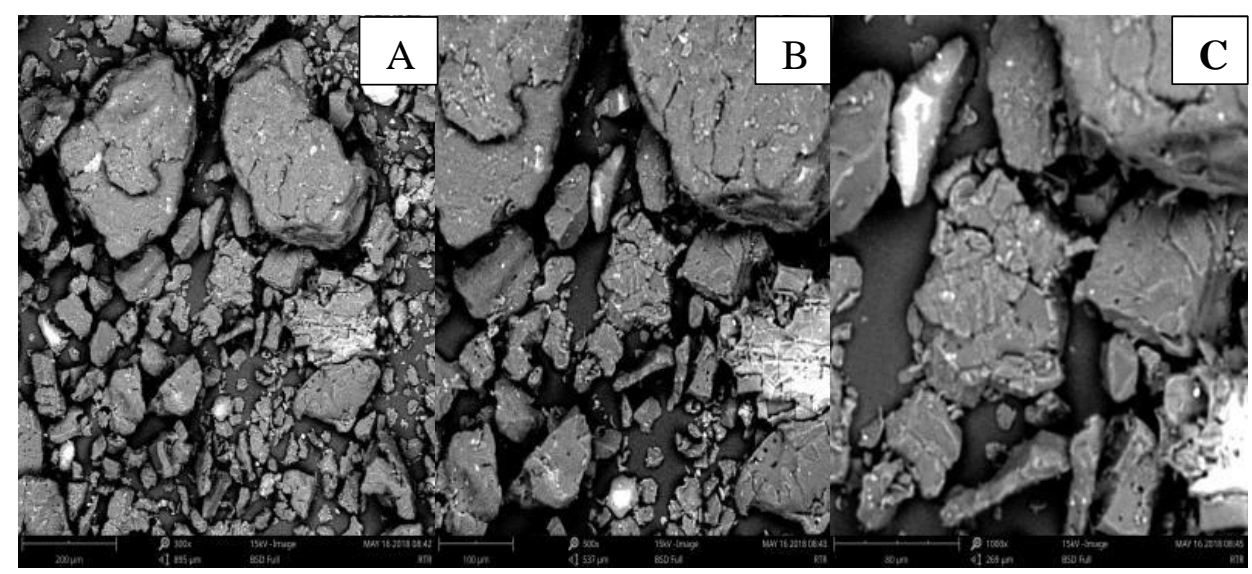

Fig. 1. SEM images of RTR at 300x (A), 500x (B) and 1000x (C) 


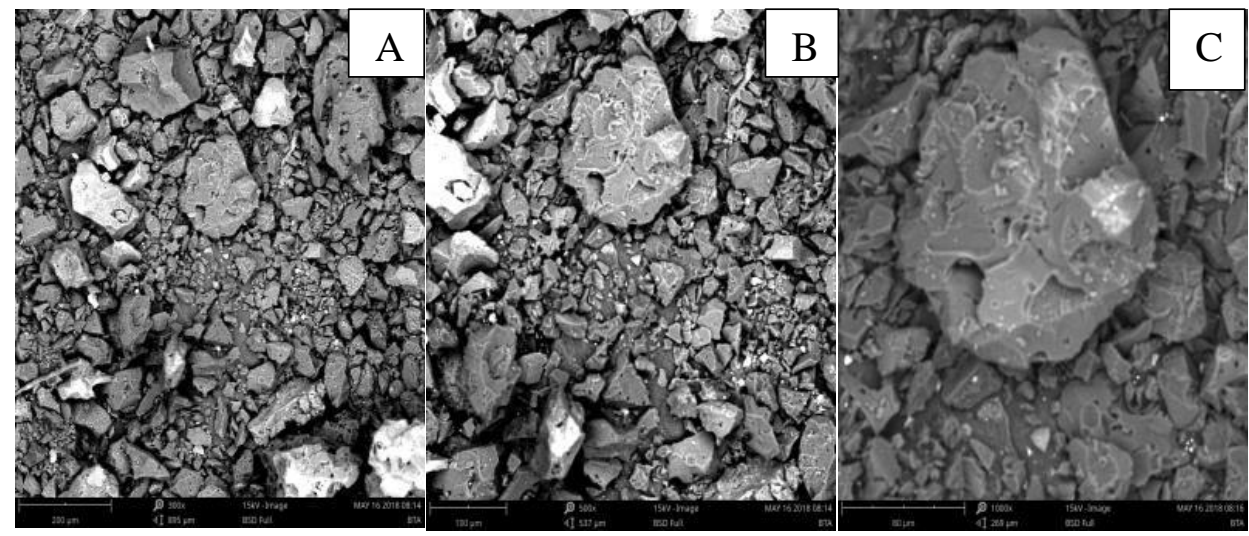

Fig. 2. SEM images of RTA at 300x (A), 500x (B) and 1000x (C).

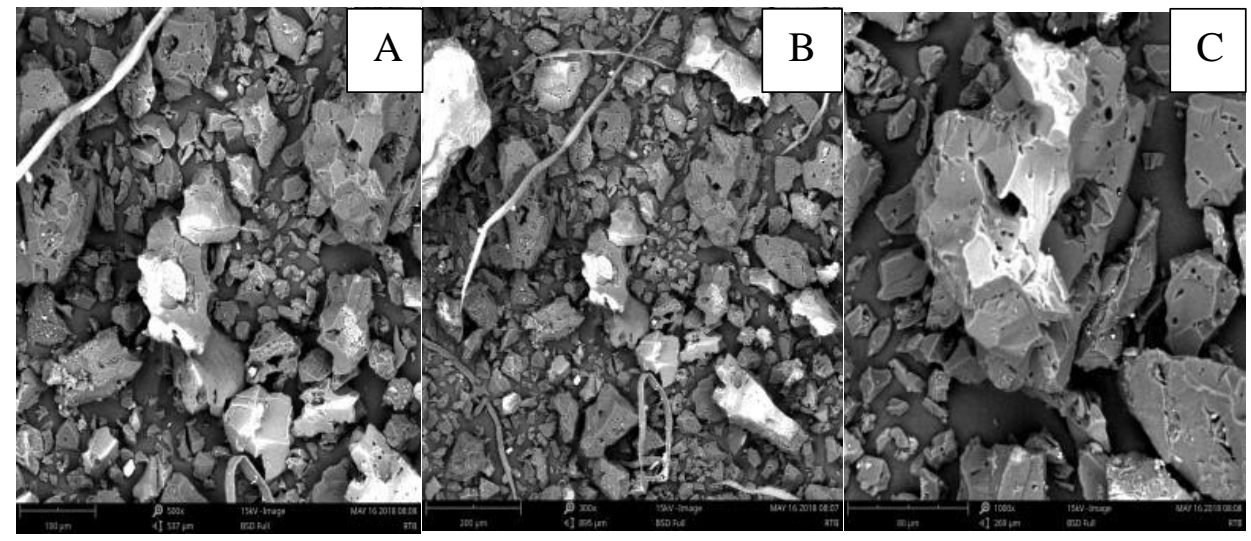

Fig. 3. SEM images of RTB at 300x (A), 500x (B) and 1000x (C)

\subsection{FTIR Spectral Analysis}

Figures 4, 5 and 6 show the FTIR spectra of raw $R$. taedigera seed powder, acid activated $R$. taedigera seed and base activated $R$. taedigera seed respectively. Again significant changes were observed in the materials in term of band shift, band disappearances and new band formations due to pyrolysis and activation of RTA and RTB. As shown in the spectra, a strong and sharp band at about $3700-3500 \mathrm{~cm}^{-1}$ due to free $\mathrm{OH}$ group, a broad band at $3600-3200 \mathrm{~cm}^{-1}$ representing bonded OH group, a band at about $3000-$ $2850 \mathrm{~cm}^{-1}$ corresponding to aliphatic $\mathrm{C}-\mathrm{H}$ group, a band at about $1820-1670 \mathrm{~cm}^{-1}$ indicating $\mathrm{C}=0$ stretch, a band in about $1385-1345 \mathrm{~cm}^{-1}$ indicating N-O stretch of nitro molecule, a band at about $1300-1000 \mathrm{~cm}^{-1}$ corresponds to C-O stretch of ester and a strong band at about $800-600 \mathrm{~cm}^{-1}$ indicating C-Cl of alkyl halide were observed in the three materials. Comparing the spectra of RTA and RTB (Figures 5 and 6) with RTR (figure 4), two new bands corresponding to free $\mathrm{OH}$ group at about $3700-3500 \mathrm{~cm}^{-1}$, new band at about $1600-1400 \mathrm{~cm}^{-1}$ corresponding to $\mathrm{C}=\mathrm{C}$ of aromatic and a band at about $1354 \mathrm{~cm}^{-1}$ corresponding to $\mathrm{C}-\mathrm{N}$ stretching of amine were observed. However, the extra band at $2374 \mathrm{~cm}^{-1}$ indicating $\mathrm{CN}$ stretch of nitrile and a band at $1241 \mathrm{~cm}^{-1}$ corresponding to CN stretch of amine observed in RTA spectral were not found in RTB spectral. The changes in the FTIR spectra of the materials may be due to the introduction of activating agents for surface modifications [54, 53] of RTA and RTB. 
Undoubtedly, the shifts in the spectra indicated the prepared materials would be of great use as adsorbents for heavy metals and dye removal. This is in line with reports of previous studies as reported by $[55,56,57]$.

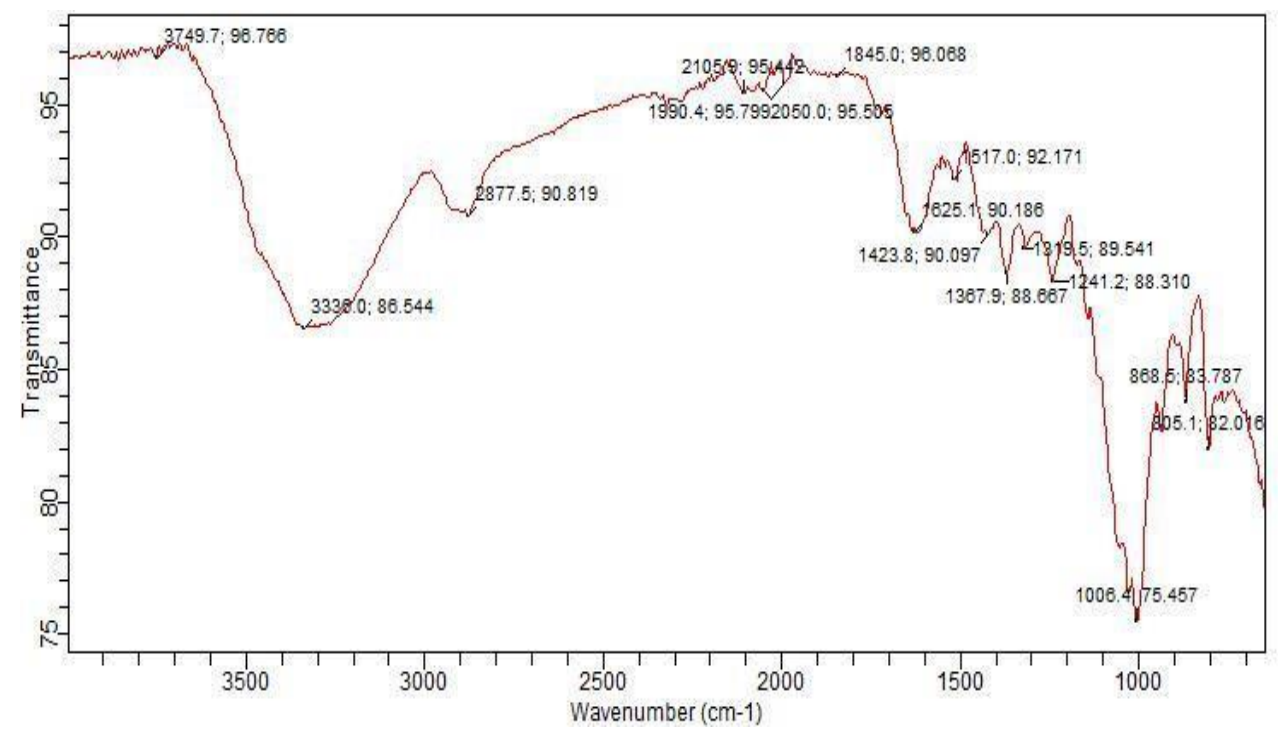

Fig. 4. FTIR Spectra of RTR

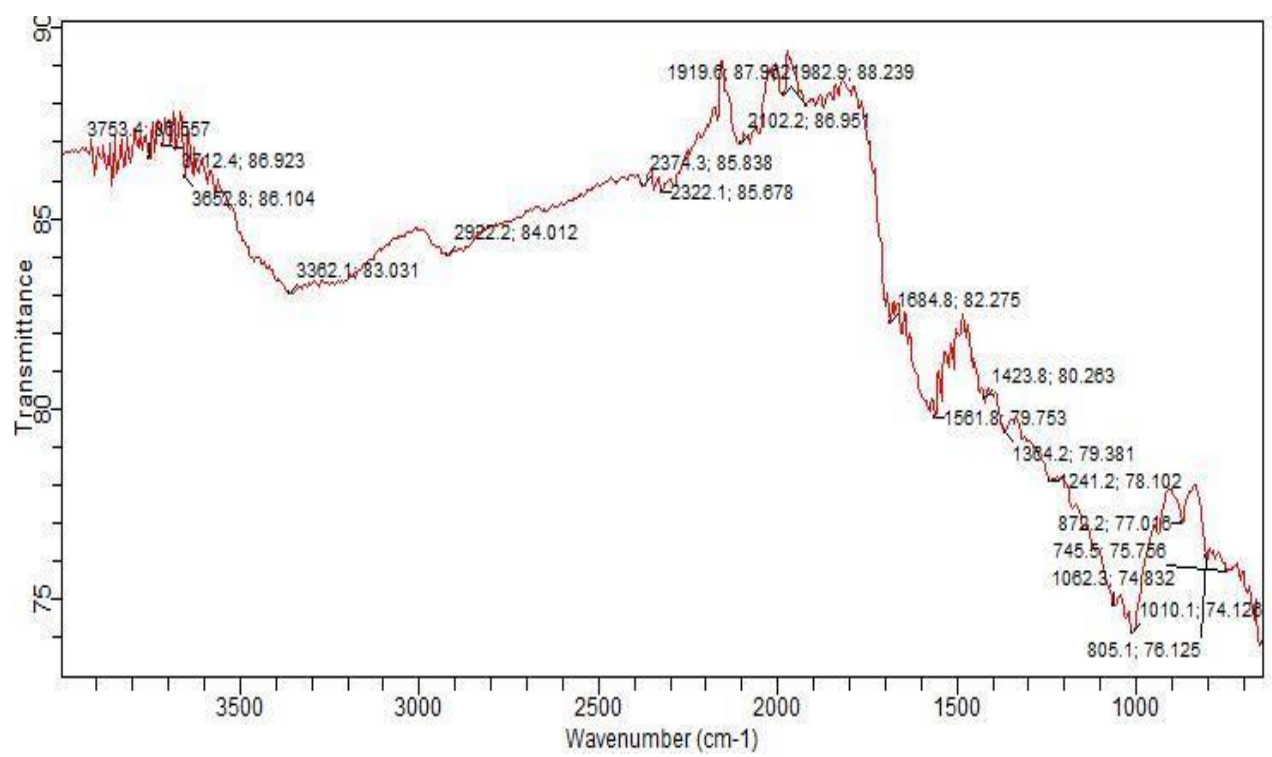

Fig. 5. FTIR Spectra of RTA 


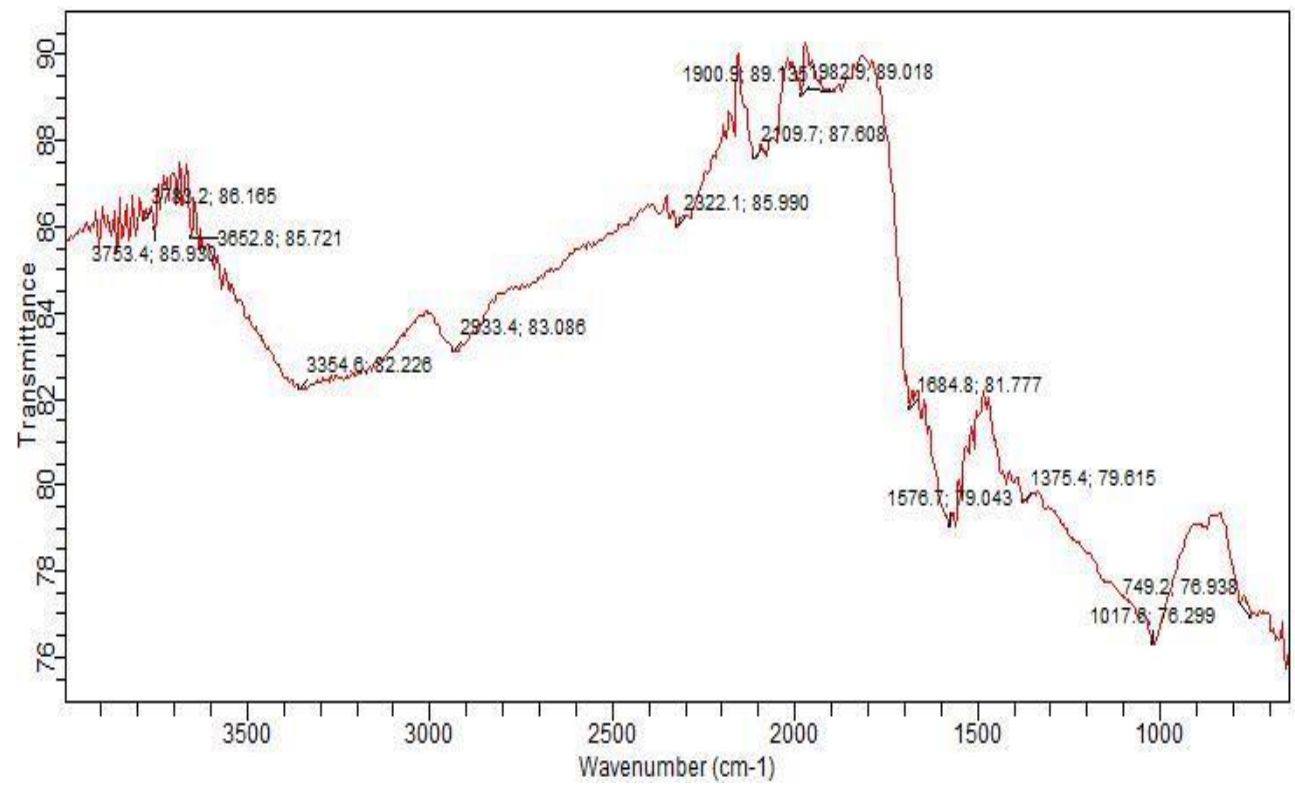

Fig. 6. FTIR Spectra of RTB

\subsection{Thermal Behaviour}

Thermogravimetric analysis (TGA) reveals the thermal stability of the materials while Differential thermogravimetric analysis (DTA) gives the temperature of the maximum decomposition rate. The TGA and DTA curves of raw $R$ taedigera, acid and base biochars are presented as Figure 7, 8 and 9 respectively. According to the results of TGA presented in Figures 7, 8, and 9, there was slight loss of weight in the materials within a temperature range of $50-130^{\circ} \mathrm{C}$. The loss of weight can be attributed to the removal of week-bonded water molecules within the materials. The second stage of weight loss which was a major weight loss in the materials was observed at around $350-500^{\circ} \mathrm{C}$ for RTR and at about $350-550^{\circ} \mathrm{C}$ for RTA and RTB. This second stage loss of weight was due to decomposition of glycosyl units of cellulose or lignin followed by the formation of char (Vilar et al., 2009). Also, as shown in the DTA Figures, the peaks corresponding to maximum degradation temperatures of RTR, RTA and RTB were observed at $380^{\circ} \mathrm{C}$, $425^{\circ} \mathrm{C}$ and $410^{\circ} \mathrm{C}$ respectively. This indicates the activated materials exhibited greater thermal stability. This may be as a result of pyrolysis and the ability of acid and base used as activating agents to further burn out more of organic compounds from the carbonized material. 


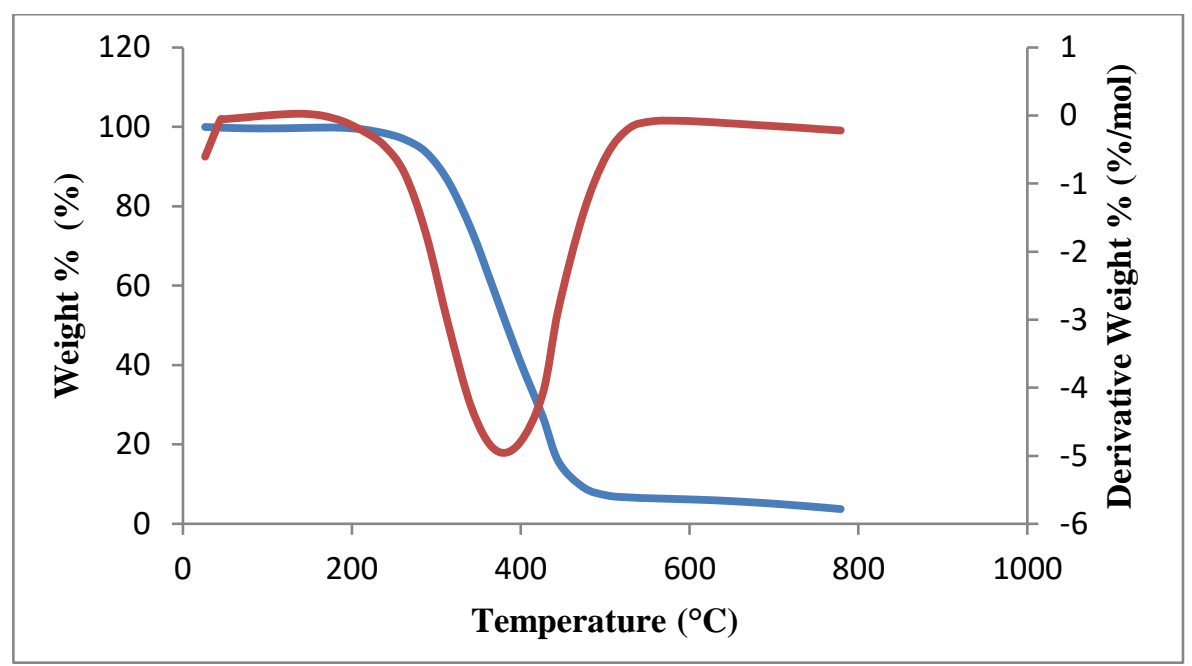

Fig. 7. TGA/DTG curves for RTR

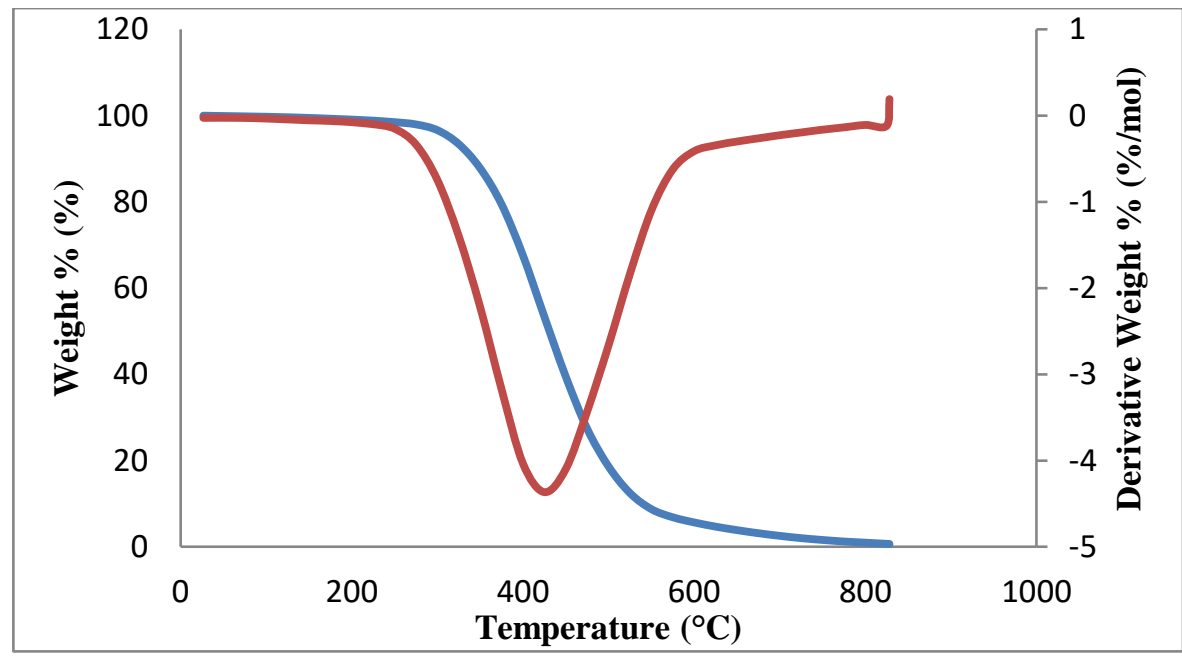

Fig. 8. TGA/DTG curves for RTA 


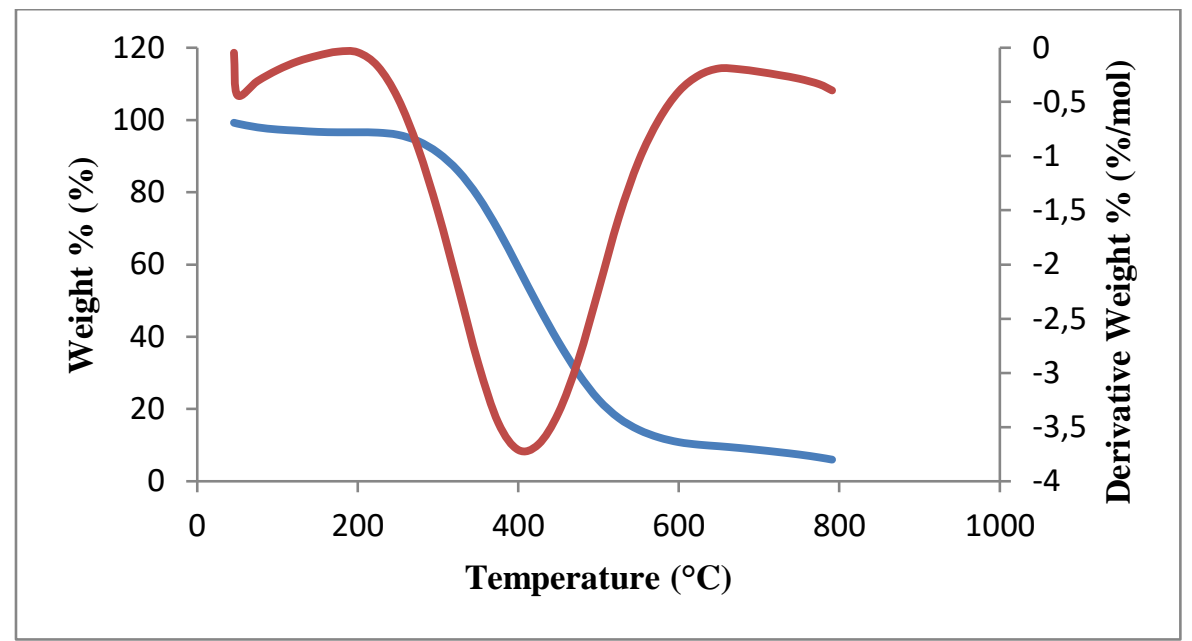

Fig. 9. TGA/DTG curves for RTB

\subsection{Results of Parameters Evaluation}

\subsubsection{Determination of Maximum Absorption Wavelength.}

Maximum absorption wavelength of the stock solution was determined using UV-1800 series spectrophotometer between the wavelength 200 and $900 \mathrm{~nm}$. The scanning revealed the maximum absorption wavelength of the methylene blue to be $659 \mathrm{~nm}$ as obtained from the curve of absorbance against wavelength as presented as Figure 10. The maximum absorption wavelength was used for subsequent determinations.

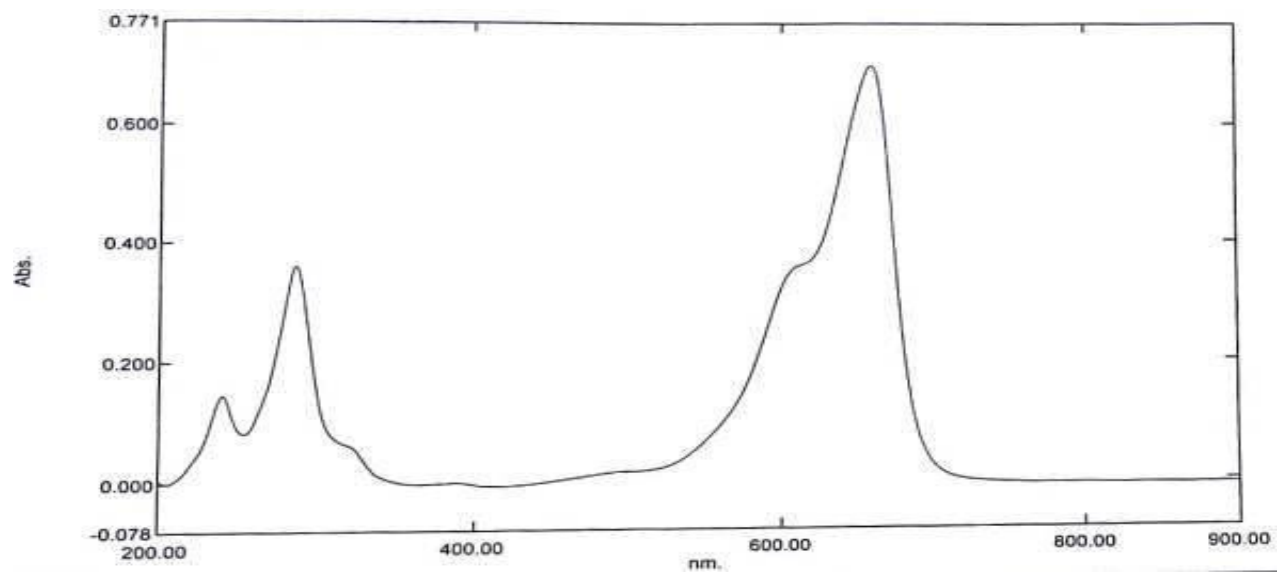

Fig. 10. Absorption Curve of Methylene Blue as a function of Wavelength

\subsubsection{Effect of Biochar Dosage}

The effect of adsorbent dosage on Methylene blue was determined at room temperature $(298 \mathrm{~K})$, adsorbent concentration $(100 \mathrm{mg} / \mathrm{L})$ and time (15 minutes). The result, as presented in Figure 11 showed an increase in adsorption as the dosage increases [58, $59,60]$ up to $0.7 \mathrm{~g}$. The increase may be due to the availability of a larger active surface area [61] and pore size. Maximum adsorptions of $99.207 \%$ and $89.997 \%$ were observed at $0.7 \mathrm{~g}$ for RTA and RTB respectively. Reduction in the adsorption was observed with a 
dosage above $0.7 \mathrm{~g}$ for both adsorbents. The reduction can be attributed to the initial vacant sites on the adsorbents being quickly and completely filled with molecules of MB.

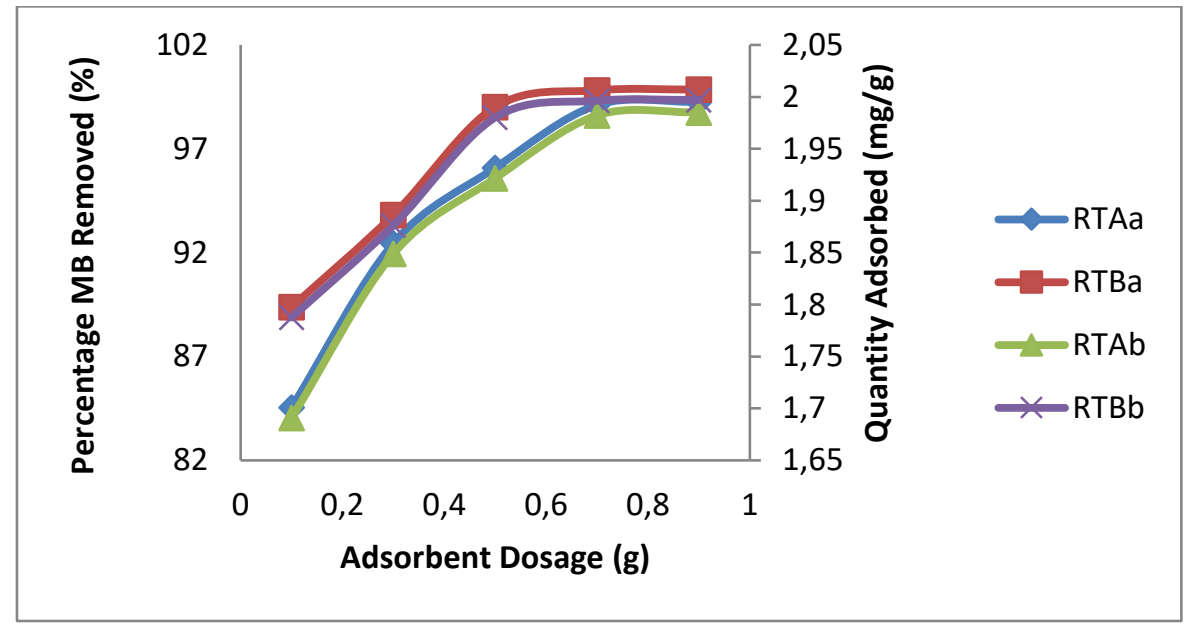

Fig. 11. Effect of dosage on adsorption capacity of RTA and RTB

RTAa and RTBa are percentage of MB removed by RTA and RTB respectively, while $\mathrm{RTAb}$ and RTBb are quantity of MB adsorbed per unit mass of RTA and RTB respectively

\subsubsection{Effect of Initial Solution Concentration}

The effect of initial methylene blue concentration was evaluated with $20.00 \mathrm{mg} / \mathrm{L}, 40.00$ $\mathrm{mg} / \mathrm{L}, 60.00 \mathrm{mg} / \mathrm{L}, 80.00 \mathrm{mg} / \mathrm{L}$ and $100.00 \mathrm{mg} / \mathrm{L}$ of methylene blue at constant temperature $(298 \mathrm{~K})$, time $(15 \mathrm{~min})$ and adsorbent dose $(0.5 \mathrm{~g})$. Figure 12 revealed that adsorption increases with concentration. This implies that the diffusion of methylene blue is accelerated with increasing concentration due to the increase in forces of attraction of the concentration gradients [62] leading to effective interactions between dye particles and adsorbent surface [63]. On the other hand, the continuous increase of the initial concentration of MB reduces the adsorption capacity of the adsorption; this may be due to the equilibrium between the MB particles and the surface of the adsorbent. 


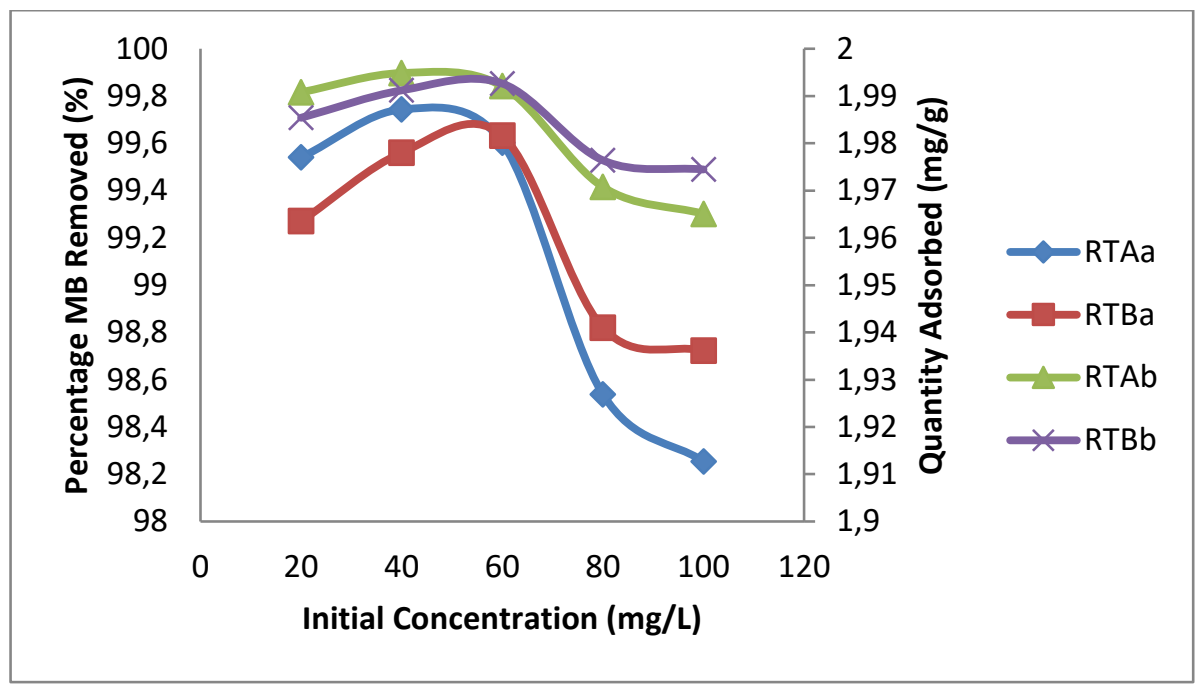

Fig. 12. Effect of initial concentration on adsorption capacity of RTA and RTB

RTAa and RTBa are percentage of MB removed by RTA and RTB respectively, while $\mathrm{RTAb}$ and RTBb are quantity of MB adsorbed per unit mass of RTA and RTB respectively

\section{Conclusion}

In the present study, new potential acidic activated Raphia taedigera seed and alkaline activated Raphia taedigera seed biochars were prepared from Raphia taedigera seed. The biochars were prepared by carbonization and chemical activation using $0.1 \mathrm{M}$ sulphuric acid and $0.1 \mathrm{M}$ sodium hydroxide to produce RTA and RTB respectively. Scanning electron microscopy (SEM), Fourier-transform infrared (FTIR) spectrophotometry, and thermogravimetric/Differential thermal analyses (TG/DTA) were carried out on the prepared biochars and raw $R$. taedigera seed.

- The results of the analyses revealed that acid and base activated materials could be excellent adsorbents for removal of dyes from industrial and agricultural wastewater.

- Considering the results from scanning electron microscope, the activated materials have aggregated and rough surface morphologies with links between surface particles creating porous structure with greater homogeneity.

- Results of thermal analyses, showed higher thermal stability of the biochars with $380^{\circ} \mathrm{C}, 425^{\circ} \mathrm{C}$ and $418^{\circ} \mathrm{C}$ maximum decomposition temperatures for RTR, RTA and RTB respectively.

- Fourier-transform infrared spectrophotometry result revealved a large number of peaks corresponding to different functional groups such as hydroxyl group, ketonic group, carboxylic group, alkene group among others, which are all capable of aiding adsorption process.

- The adsorbents performance evaluations using different initial concentrations of methylene blue and adsorbent dosage were evaluated. The results revealved the percentage efficiencies of RTA and RTB to be within $98.245 \%$ to $99.743 \%$ and $98.723 \%$ to $99.632 \%$ respectively for the methylene blue initial concentrations range of 20 to $100 \mathrm{mg} / \mathrm{L}$. Also, $84.542 \%$ to $99.256 \%$ and 
$89.375 \%$ to $99.851 \%$ efficiencies were observed for RTA and RTB respectively, for the effect of adsorbent dosages range of $0.1 \mathrm{~g}$ to $0.9 \mathrm{~g}$.

The results of the preliminary investigations showed great potentials of the materials being used as adsorbents. Further studies are required to investigate the mechanism involved and the efficiencies of the prepared materials.

\section{Acknowledgement}

The authors appreciate the efforts of the staff of the department of chemistry, Federal Univesity of Technology, Akure and the department of Science Technology, The Federal Polytechnic, Ado-Ekiti. This research did not receive any grant from funding agencies in the public, commercial, or not-for-profit sectors.

\section{Reference}

[1] Rajendran S, Khan MM, Gracia F, Qin J, Gupta VK, Arumainathan S. Ce3+-ion-induced visible-light photocatalytic degradation and electrochemical activity of $\mathrm{ZnO} / \mathrm{CeO} 2$ nanocomposite, Sci. Rep., 2016; 5: 31641. https://doi.org/10.1038/srep31641

[2] Vijayakumar G, Tamilarasan R, Dharmendirakumar MM. Adsorption, Kinetic, Equilibrium and Thermodynamic studies on the removal of basic dye Rhodamine-B from aqueous solution by the use of natural adsorbent perlite. J. Mater. Environ. Sci., 2012; 3: 157- 170.

[3] Wawrzkiewicz M, Hubicki Z. Removal of tartrazine from aqueous solu-tions by strongly basic polystyrene anion exchange resins. J. Hazard. Mater. 2009; 164: 502509. https://doi.org/10.1016/j.jhazmat.2008.08.021

[4] Poinern GEJ, Senanayake G, Shah N, Thi-Le XN, Parkinson GM, Fawcett B. Adsorption of the aurocyanide, complex on granular activated carbons derived from macadamia nut shells - A preliminary study. Miner. Eng., 2011; 24: 1694-1702 https://doi.org/10.1016/i.mineng.2011.09.011

[5] Kirubakaran CJ, Krishnaiah K, Seshadri SK. Experimental study of the production of activated carbon from coconut shells in a fluidized bed reactor. Ind. Eng. Chem. Res., 1991; 30: 2411-2416. https://doi.org/10.1021/ie00059a008

[6] Arris S, Bencheikh LM, Miniai HA. Preparation and characterisation of an natural adsorbent used for elimination of pollutants in wastewater, Energy Procedia. 2012; 18: $1145 \quad-\quad 1151$. doi: 10.1016/j.egypro.2012.05.129 https://doi.org/10.1016/i.egypro.2012.05.129

[7] Saravanan R, Sacari E, Gracia F, Khan MM, Mosquera E, GuptaVK. Conducting PANI stimulated $\mathrm{ZnO}$ system for visible light photocatalytic degradation of colored dyes. Mol. Liq. J., 2016; 221: 1029-1033 https://doi.org/10.1016/j.molliq.2016.06.074

[8] Gupta VK, Jain R, MittalA, Tawfik A, Saleh A, Naya A, Agarwal S, Sikarwa S. Photocatalytic degradation of toxic dye amaranth on TiO2/UV in aqueous suspensions. Mater. Sci. Eng. C, 2012; 32: 12-17

[9] Gupta VK, Jain R, Nayak A, Agarwal S, Shrivastava M. Removal of the hazardous dye Tartrazine by photodegradation on titanium dioxide surface. J. Hazard. Mater., 2011; 31: 1062-1067 https://doi.org/10.1016/j.msec.2011.03.006

[10] Saleh TA, Gupta VK. Photo-catalyzed degradation of hazardous dye methyl orange by use of a composite catalyst consisting of multi walled carbon nanotubes and titanium dioxide. J. Colloid Interface Sci., 2012; 371: 101-106 https://doi.org/10.1016/i.jcis.2011.12.038 
[11] Saravanan R, Gracia F, Khan MM, Poornima V, Gupta VK, Narayanan A. ZnO/CdO nanocomposites for textile effluent degradation and electrochemical detection. J. Mol. Liq., 2015; 209: 374-380. https://doi.org/10.1016/j.molliq.2015.05.040

[12] Saravanan R, Gupta VK, Mosquera E, Gracia F. Preparation and characterization of V205/ZnO nanocomposite system for photocatalytic application. J. Mol. Liq., 2014; 198: 409-412 https://doi.org/10.1016/i.molliq.2014.07.030

[13] Behnajady MA, Modirshahla N, Ghanbary F. A kinetic model for the decolorization of C. I. Acid yellow 23 by Fenton process. J. Hazard. Matter., 2007; 148: 98-102 https://doi.org/10.1016/j.jhazmat.2007.02.003

[14] Garcia-Montano J, Ruiz N, Munoz I, Domenech X, Garcia-Hortal JA, Torrades F, Pearl J. Environmental assessment of different Photo-Fenton approaches for commercial reactive dye removal. J. Hazard. Mater., 2007; 138: 218 - 225 https://doi.org/10.1016/j.jhazmat.2006.05.061

[15] Abbasi M, Asi NR. Sonochemical degradation of Basic Blue 41 dye assisted by nano TiO2 and H2O2. J. Hazard. Mater., 2008; 153: 942 - 947 https://doi.org/10.1016/j.jhazmat.2007.09.045

[16] Saleh TA, Gupta VK. Column with CNT/magnesium oxide composite for lead(II) removal from water. Envir. Sci . Poll. Res., 2012; 19: 1224-1228 https://doi.org/10.1007/s11356-011-0670-6

[17] Lorenc-Grabowsk E, Gryglewic G. Adsorption characteristics of Congo red on coalbased mesoporous activated carbon. Dyes Pigm., 2007; 74: 34-40. https://doi.org/10.1016/i.dyepig.2006.01.027

[18] Malik PK, Sanyal SK. Kinetics of decolorization of azo dyes in wastewater by UV/H2O2 process. Sep. Purif. Technol., 2004; 36: 167-170 https://doi.org/10.1016/S1383-5866(03)00212-0

[19] Banat IM, Nigam P, Singh R. Marchant, Microbial decolorization of textile dye containing effluents: a review. Bioresour. Technol., 1996; 58: 217-227. https://doi.org/10.1016/S0960-8524(96)00113-7

[20] Malik PK, Saha SK. Oxidation of direct dyes with hydrogen peroxide using ferrous ion as catalyst. Sep. Purif. Technol., 2003; 31: 241-250. https://doi.org/10.1016/S1383-5866(02)00200-9

[21] Asfaram A, Ghaedia M, Hajati S. Goudarzi A, Alipanahpour Dil E. Screening and optimization of highly effective ultrasound-assisted simultaneous adsorption of cationic dyes onto Mn-doped Fe304-nanoparticle-loaded activated carbon Ultrason. Sonochem., 2017; 34: 1-12 https://doi.org/10.1016/j.ultsonch.2016.05.011

[22] Alipanahpour Dil E, Ghaedi M, Asfaram A, Hajati S, Mehrabi F, Goudarzi A. Preparation of nanomaterials for the ultrasound-enhanced removal of $\mathrm{Pb} 2+$ ions and malachite green dye: chemometric optimization and modelling Ultrason. Sonochem., 2017; 34: 677-691 https://doi.org/10.1016/j.ultsonch.2016.07.001

[23] Ghaedi M, Zare Khafri H, Asfaram A, Goudarzi A. Response surface methodology approach for optimization of adsorption of Janus Green B from aqueous solution onto $\mathrm{ZnO} / \mathrm{Zn}(\mathrm{OH}) 2-\mathrm{NP}-\mathrm{AC}$ : kinetic and isotherm study. Spectrochim. Acta. A, 2015; 152: 233-240 https://doi.org/10.1016/j.saa.2015.06.128

[24] Mazaheri H, Ghaedi M, Asfaram A, Hajati S. Performance of CuS nanoparticle loaded on activated carbon in the adsorption of methylene blue and bromophenol blue dyes in binary aqueous solutions: using ultrasound power and optimization by central composite design. J. Mol. Liq., 2016; 219: 667-676 https://doi.org/10.1016/j.molliq.2016.03.050

[25] Mittal A, Mittal J, Malviya A, Kaur D, Gupta VK. Decoloration treatment of a hazardous triarylmethane dye, light green SF (Yellowish) by waste material 
adsorbents. J. Colloid Interface Sci., 2010; 342: 518-527 https://doi.org/10.1016/i.jcis.2009.10.046

[26] Gupta VK, Nayak A. Cadmium removal and recovery from aqueous solutions by novel adsorbents prepared from orange peel and Fe203 nanoparticles. Chem. Eng. J., 2012; 180: 81-90 https://doi.org/10.1016/j.cej.2011.11.006

[27] Gupta VK, Nayak A, Agarwal S. Bioadsorbents for remediation of heavy metals: current status and their future prospects. Environ. Eng. Res., 2015; 20: 1-18 https://doi.org/10.4491/eer.2015.018

[28] Gupta VK, Nayak A, Bhushan B, Agarwal S. A critical analysis on the efficiency of activated carbons from low-cost precursors for heavy metals remediation. Crit. Rev. $\begin{array}{lllll}\text { Environ. } & \text { Sci. } & \text { Technol., } & \text { 2015; }\end{array}$ https://doi.org/10.1080/10643389.2013.876526

[29] Saleh TA, Gupta VK. Processing methods, characteristics and adsorption behavior of tires derived carbons: a review. Adv. Colloid Interface Sci., 2014; 211: 92-100 https://doi.org/10.1016/i.cis.2014.06.006

[30] Alok M, Jyoti M, Arti M, Gupta VK. Removal and recovery of Chrysoidine Y from aqueous solutions by waste materials, Journal of Colloid and Interface Science, 2010; 344: 497-507. https://doi.org/10.1016/j.jcis.2010.01.007 https://doi.org/10.1016/j.jcis.2010.01.007

[31] Deng H, Yang L, Tao G, Dai J. Preparation and characterization of activated carbon from cotton stalk by microwave assisted chemical activation-application in methylene blue adsorption from aqueous solution., Journal of Hazardous Materials 2009; 166: 1514-1521. https://doi.org/10.1016/j.jhazmat.2008.12.080

[32] Liu QS, Zheng T, Wang P, Guo L. Preparation and characterization of activated carbon from bamboo by microwave-induced phosphoric acid activation. Industrial Crops and Products, 2010; 31: $233 \quad-238$. https://doi.org/10.1016/j.indcrop.2009.10.011

[33] Saka C. BET, TG-DTG, FT-IR, SEM, iodine number analysis and preparation of activated carbon from acorn shell by chemical activation with $\mathrm{ZnCl} 2$. Journal of Analytical and Applied Pyrolysis, 2012; 95: 21-24. https://doi.org/10.1016/i.jaap.2011.12.020

[34] Kamaraj M, Umamaheswari J. Preparation and characterization of Groundnut shell activated carbon as an efficient adsorbent for the removal of Methylene blue dye from aqueous solution with microbiostatic activity. Journal of Materials and Environmental Sciences, 2017; 8: 2019-2025

[35] Malik R, Ramteke D, Wate S. Adsorption of malachite green on groundnut shell waste based powdered activated carbon. Waste Management, 2007; 27: 1129-1138. https://doi.org/10.1016/j.wasman.2006.06.009

[36] Tsai W, Chang C, Lin M, Chien S, Sun H, Hsieh M. Adsorption of acid dye onto activated carbons prepared from agricultural waste bagasse by $\mathrm{ZnCl} 2$ activation. Chemosphere 2001; 45: 51-58. https://doi.org/10.1016/S0045-6535(01)00016-9

[37] AbdulRahman A, Latiff1 AAA, Daud Z, Ridzuan MB, N F M D, Jagaba AH. Preparation and Characterization of Activated Cow Bone Powder for the Adsorption of Cadmium from Palm Oil Mill Effluent. IOP Conf. Series: Materials Science and Engineering, 2016; $\quad$ 136: $\quad 012045 \quad$ doi:10.1088/1757-899X/136/1/012045 https://doi.org/10.1088/1757-899X/136/1/012045

[38] Lua AC, Guo J. Preparation and characterization of activated carbons from oil-palm stones for gas-phase adsorption. Colloids and Surfaces A: Physicochemical and Engineering Aspects, 2001; 179: 151-162. https://doi.org/10.1016/S0927$\underline{7757(00) 00651-8}$ 
[39] Li W, Yang K, Peng J, Zhang L, Guo S, Xia H. Effects of carbonization temperatures on characteristics of porosity in coconut shell chars and activated carbons derived from carbonized coconut shell chars. Industrial Crops and Products, 2008; 28: 190-198. https://doi.org/10.1016/j.indcrop.2008.02.012

[40] Kilic M, Apaydin-Varol E, Pütün AE. Adsorptive removal of phenol from aqueous solutions on activated carbon prepared from tobacco residues: Equilibrium, kinetics and thermodynamics. Journal of Hazardous Materials, 2011; 189: 397-403. https://doi.org/10.1016/i.jhazmat.2011.02.051

[41] Martinez M, Torres M, Guzman C, Maestri D. Preparation and characteristics of activated carbon from olive stones and walnut shells. Industrial Crops and Products, 2006; 23: 23-28. https://doi.org/10.1016/j.indcrop.2005.03.001

[42] Sentorun-Shalaby C, Ucak-Astarhoglu MG, Artok L, Sarica C. Preparation and characterization of activated carbons by one-step steam pyrolysis/activation from apricot stones. Microporous and Mesoporous Materials, 2006; 88: 126-134 https://doi.org/10.1016/i.micromeso.2005.09.003

[43] Hayashi J, Horikawa T, Takeda I, Muroyama K, Nasir Ani F. Preparing activated carbon from various nutshells by chemical activation with K2CO3. Carbon, 2002; 40: 2381-2386. https://doi.org/10.1016/S0008-6223(02)00118-5

[44] Momcilocic M, Purenovic M, Bojic A, Zarubica A, Randelovic M. Removal of lead (II) ions from aqueous solutions by adsorption onto pine cone activated carbon. Desalination, 2011; 276: 53-59. https://doi.org/10.1016/i.desal.2011.03.013

[45] Angin D. Production and characterization of activated carbon from sour cherry stones by zinc chloride. Fuel, 2014; 115: 804-811. https://doi.org/10.1016/j.fuel.2013.04.060

[46] Bailey LJ. Certain palms of Panama. Gentes Herbarium, 1935; 3: 33-116.

[47] Allen PH. Rain forest palms of Golfo Dulce. Principle, 1965a; 9: 48-66.

[48] Henderson A. Palms of the Amazon. Oxford University Press, Oxford, England, 1996.

[49] Abegunde SM. Proximate Composition, Phytochemical Analysis and Elemental Characterization of Raphia taedigera Seed. Asian Journal of Chemical Sciences, 2018; 5: 1 - 8. https://doi.org/10.9734/AJOCS/2018/45819

[50] Dransfield J, Uhl NW, Asmussen-Lange CB, Baker WJ, Harley MM, Lewis CE. Genera Palmarum - Evolution and Classification of the Palms. Royal Botanic Gardens, Kew, 2008.

[51] Li J, Wang X, Zhao G, Chen C, Chai Z, Alsaedi A. Metal-organic framework-based materials: superior adsorbents for the capture of toxic and radioactive metal ions. Chemical Society Review, 2018; 27: 2322 - 2356. 10.1039/C7CS00543A https://doi.org/10.1039/C7CS00543A

[52] Anderson R, Mori S. A preliminary investigation of Raphia palm swamps. Puerto Viejo, Costa Rica. Turrialba, 1967; 17: 221-224.

[53] Bello OS, Adegoke KA, Akinyunni 00. Preparation and characterization of a novel adsorbent from Moringa oleifera leaf. Appl Water Sci., 2017; 7: 1295-1305 DOI 10.1007/s13201-015-0345-4 https://doi.org/10.1007/s13201-015-0345-4

[54] Al-Ghouti MA, Khraishe M, Allen SJ, Ahmad MN. The removal of dyes from textile wastewater: a study of the physical characteristics and adsorption mechanisms of diatomaceous earth. J Environ Manag., 2013; 69: 229. https://doi.org/10.1016/j.jenvman.2003.09.005

[55] Bekci Z, Seki Y, Cavas L. Removal of malachite green by using an invasive marine alga Caulerpa racemosa var. Cylindracea. J Hazard Mater, 2009; 161: 1454-1460. https://doi.org/10.1016/j.jhazmat.2008.04.125 
[56] Arabi M, Ghaedi M, Ostovan A. Development of a Lower Toxic Approach Based on Green Synthesis of Water-Compatible Molecularly Imprinted Nanoparticles for the Extraction of Hydrochlorothiazide from Human Urine. ACS Sustainable Chemistry \& Engineering 2017; 5: 3775-3785. doi:10.1021/acssuschemeng.6b02615 https://doi.org/10.1021/acssuschemeng.6b02615

[57] Sekhar CP, Kalidhasan S, Rajesh V, Rajesh N. Biopolymer adsorbent for the removal of malachite green from aqueous solution. Chemosphere, 2009; 77: 842-847 https://doi.org/10.1016/i.chemosphere.2009.07.068

[58] Kumar KK, Prasad MK, Baburao G, Sudhakar M, Sivajyothi J, Sathish T, Murthy VR. A fortunate marine algae biomass, Sargassum cinereum for removal of $\mathrm{Pb}(\mathrm{II})$ : Studies on thermodynamics, kinetics and characterization. Desalination and Water Treatment, 2018; 116: 179-186 doi: 10.5004/dwt.2018.22544 https://doi.org/10.5004/dwt.2018.22544

[59] Sogbochi E, Balogoun CK, Dossa CPA, Sohounhloue DCK. Evaluation of Adsorption Capacity of Methylene Blue in Aqueous Medium by Two Adsorbents: The Raw Hull of Lophira Lanceolata and Its Activated Carbon. American Journal of Physical Chemistry, 2017; 6: 76 - 87.. https://doi.org/10.11648/j.ajpc.20170605.11

[60] HAMEED AM, Bassim H. Adsorption of methyl violet dye on acid modified activated carbon: isotherms and thermodynamics. Journal of Applied Sciences in Environmental Sanitation, 2010; 5: 161-170.

[61] Saleh TA, Gupta VK. Photo-catalyzed degradation of hazardous dye methyl orange by use of a composite catalyst consisting of multi-walled carbon nanotubes and titanium dioxide. Journal of Colloid and Interface Science, 2012; 371: 101-106. doi.org/10.1016/j.jcis.2011.12.038 https://doi.org/10.1016/j.jcis.2011.12.038

[62] Mahmut 0. Phosphate adsorption characteristics of alunite to be used as a cement additive. Cement and Concrete Research, 2003; 33: 1583-1587. https://doi.org/10.1016/S0008-8846(03)00113-3

[63] Robati D, Mirza B, Rajabi M, Moradi O, Tyagi I, Agarwal S, Gupta VK. Removal of hazardous dyes-BR 12 and methyl orange using graphene oxide as an adsorbent from aqueous phase. Chemical Engineering Journal, 2016; 284: 687-697 doi.org/10.1016/j.cej.2015.08.131 https://doi.org/10.1016/j.cej.2015.08.131 